\title{
Upaya Hukum Cessionaris Terhadap Hak Tagih Atas Jaminan Hak Tanggungan Berdasarkan Pengalihan Hutang (Cessie)
}

\author{
Diana Fitriana $^{1}$, Abdul Wahid ${ }^{2}$ \\ ${ }^{1}$ Fakultas Hukum, Universitas Bhayangkara Jakarta Raya \\ ${ }^{2}$ Fakultas Hukum, Universitas Muhammadiyah Cirebon \\ Email: diana.fitriana@dsn.ubharajaya.ac.id; abdul.wahid@umc.ac.id
}

Received : 17 Sep 2021 | Revised : 26 Oct 2021 | Accepted : 22 Nop 2021 | Published : 9 Dec 2021

\begin{abstract}
The sale and purchase and transfer of accounts receivable (Cessie) from the bank to a third party (the new creditor) are by applicable legal provisions, so legally the third party (the new creditor) is the new creditor who has the right to collect on the debtor's obligations based on the credit agreement. However, in reality, since the New Creditor received the transfer of Accounts Receivable on behalf of the debtor, he did not make payments on his obligations based on the credit agreement. The purpose of this research is to find out how the cessionary legal remedies against the right to collect on the guarantee of mortgage based on debt transfer (cessie). The results of this study indicate that the cessionary legal action against the right to collect on collateral based on the transfer of debt (cessie) is filing a lawsuit for default or breaking promises on the credit agreement at the District Court. Cessie buyers must apply to the District Court first so that the District Court's decision can become the basis for the change of name (in its decision, the District Court orders the National Land Agency (BPN) to transfer the name written on the certificate to the name of the cessie buyer.
\end{abstract}

Keywords: Legal Efforts; Cessionaris; Mortgage right; Cessie.
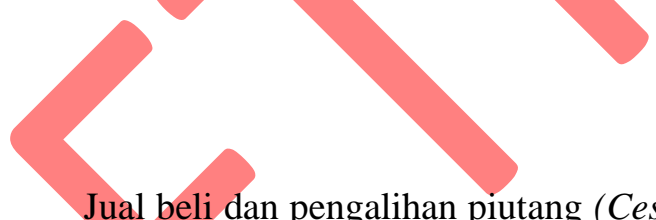

pengalihan piutang (Cessie) dari bank kepada pihak ketiga (kreditur baru) telah sesuai dengan ketentuan hukum yang berlaku, sehingga secara hukum pihak ketiga (kreditur baru) berkedudukan sebagai Kreditur baru yang memiliki hak tagih atas kewajiban debitur berdasarkan perjanjian kredit. Namun kenyataannya sejak Kreditur Baru menerima pengalihan Piutang atas nama debitur tidak melakukan pembayaran atas kewajibannya berdasarkan perjanjian kredit. Tujuan dari penelitian ini adalah untuk mengetahui bagaimana upaya hukum cessionaris terhadap hak tagih atas jaminan hak tanggungan berdasarkan pengalihan hutang (cessie). Hasil penelitian ini bahwa upaya hukum cessionaris terhadap hak tagih atas jaminan hak tanggungan berdasarkan pengalihan hutang (cessie) yaitu mengajukan gugatan wanprestasi atau ingkar janji atas perjanjian kredit pada Pengadilan Negeri. Pembeli cessie harus mengajukan permohonan ke Pengadilan Negeri terlebih dahulu, agar dari ketetapan Pengadilan Negeri tersebut dapat menjadi dasar peralihan nama (didalam penetapannya, Pengadilan Negeri memerintahkan Badan Pertanahan Nasional (BPN) untuk dapat mengalihkan nama yang tertulis di sertifikat menjadi nama pembeli cessie.

Kata Kunci: Upaya Hukum; Cessionaris; Hak Tanggungan; Cessie. 


\section{PENDAHULUAN}

Debitur telah menandatangani Perjanjian Kredit dengan Bank sebagai Kreditur, dalam Perjanjian Kredit tersebut Debitur telah meminjam uang kepada Bank. Untuk menjamin pelaksanakan pembayaran kredit tersebut Debitur telah menandatangani pengakuan hutang kepada Bank dan memberikan jaminan (agunan) kredit berupa sebidang tanah dan bangunan yang berdiri diatasnya. Terhadap jaminan tanah dan bangunan tersebut atas kuasa Debitur oleh Bank telah dibebani Hak Tanggungan sebagaimana tercatat dalam Akta Pemberian Hak Tanggungan (APHT). Kemudian atas dasar Akta Pemberian Hak Tanggungan (APHT) tersebut oleh bank didaftarkan di Badan Pertanahan Nasional (BPN) sehingga terbit Sertipikat Hak Tanggungan.

Pembayaran angsuran oleh debitur semula lancar, akan tetapi kemudian debitur tidak pernah lagi membayar angsurannya kepada bank, meskipun telah diperingati berulang kali. Oleh karena debitur telah lalai melaksanakan kewajiban pembayaran fasilitas kredit dan tindakannya cidera janji atas perjanjian kredit (wanprestasi). Akhirnya, pihak bank telah menjual dan mengalihkan piutang atas nama debitur kepada pihak ketiga sebagaimana tercatat dalam Akta Pengalihan Piutang (Cessie) yang dibuat dihadapan Notaris dan PPAT. Berdasarkan Akta Pengalihan Piutang (Cessie) tersebut dengan segala hak dan kewajiban bank sehubungan dengan perjanjian kredit, berikut semua janji-janji accessoirnya, termasuk hak-hak atas agunan kredit secara hukum beralih kepada pihak ketiga (kerditur baru). Dengan demikian berdasarkan akta cessie maka Pemegang hak tanggungan secara hukum beralih dari bank kepada pihak ketiga sebagaimana tercatat dalam Grosse Sertipikat Hak Tanggungan. Sebagai kreditur baru maka memiliki hak tagih atau hak untuk menuntut pemenuhan kewajiban debitur berdasarkan perjanjian kredit. Sebagaimana dijelaskan dalam Pasal 613 paragraf 3 Kitab Undang-undang Hukum Perdata, suatu pengalihan atau penyerahan piutang haruslah diberitahukan kepada si berhutang dalam hal ini debitur.

Kemudian pihak ketiga (kreditur baru) melakukan undangan untuk memberitahukan mengenai Cessie kepada debitur melalui surat Somasi dalam pemberitahuan tersebut pihak ketiga (kreditur baru) menggantikan kedudukan bank sebagai kreditur baru terhadap debitur, dengan pengalihan piutang dari bank kepada kreditur baru, debitur telah memberikan persetujuan dimuka sebagaimana tercantum dalam ketentuan dan syarat-syarat perjanjian kredit Pasal 20 ayat 1 dan $2 .{ }^{1}$

Oleh karenanya, berdasarkan uraian tersebut jual beli dan pengalihan piutang (Cessie) dari bank kepada pihak ketiga (kreditur baru) telah sesuai dengan ketentuan hukum yang berlaku, sehingga secara hukum pihak ketiga (kreditur baru) berkedudukan sebagai Kreditur baru yang memiliki hak tagih atas kewajiban debitur berdasarkan perjanjian kredit. ${ }^{2}$ Namun kenyataannya sejak Kreditur Baru menerima pengalihan

\footnotetext{
${ }^{1}$ Pasal 20 ayat (1): Debitur menyetujui dan sepakat untuk memberikan hak sepenuhnya kepada Bank untuk menyerahkan piutang ( Cessie ) dan atau tagihan bank terhadap Debitur berikut semua janjijanji accessoirnya, termasuk hak-hak atas agunan kredit kepada pihak lain yang ditetapkan oleh bank sendiri, setiap saat diperlukan oleh bank. Pasal 20 ayat (2): Apabila bank melaksanakan penyerahan piutang (Cessie) kepada pihak lain sebagaimaan dimaksud ayat (1), bank tidak wajib memberitahukan kepada Debitur, sehingga apabila kemudian pihak yang menerima penyerahan piutang (menerima Cessie) menjalankan haknya sebagai kreditur, maka hal demikian sudah dapat dinyatakan sepenuhnya semata-mata berdasarkan perjanjian yang dibuat antara bank dengan pihak yang menerima penyerahan piutang dan adanya pengalihan piutang ini tidak mempengaruhi sama sekali pelaksanaan kewajiban Debitur sesuai dengan perjanjian kredit ini.

${ }^{2}$ Perjanjian Kredit merupakan bukti yang sah atas kewajiban debitur kepada bank dan sesuai dengan prinsip Pasal 1338 Kitab Undang-undang Hukum Perdata janji tersebut mengikat debitur dan berlaku sebagai undang-undang.
} 
Piutang atas nama debitur tidak melakukan pembayaran atas kewajibannya berdasarkan perjanjian kredit.

\section{METODE}

Jenis Penelitian yang digunakan dalam penulisan ini adalah jenis penelitian hukum normatif, sumber hukum yang digunakan adalah data sekunder yaitu data yang diperoleh melalui studi kepustakaan, yaitu bahan hukum primer, bahan hukum sekunder, dan bahan hukum tersier. ${ }^{3}$ Untuk metode pendekatan dalam penelitian ini adalah pendekatan peraturan perundang-undangan (statue aproach) ${ }^{4}$

Pengumpulan bahan hukum dilakukan dengan pencatatan teori-teori yang diperoleh dari literatur-literatur serta Peraturan Perundang-undang, dari jawaban tersebut dilakukan pencatatan sederhana yang kemudian diolah dan dianalisa. ${ }^{5}$ Metode analisis ini berupa metode preskriptif yaitu metode analisis yang memberikan penilaian (justifikasi) tentang obyek yang diteliti apakah benar atau salah, atau apa yang seyogyanya menurut hukum. ${ }^{6}$

\section{PEMBAHASAN Upaya Hukum}

\section{Pengertian}

Upaya hukum adalah upaya atau alat untuk mencegah atau memperbaiki kekeliruan dalam suatu putusan. Upaya hukum ialah suatu upaya yang diberikan oleh undang-undang bagi seseorang maupun badan hukum dalam hal tertentu untuk melawan putusan hakim sebagai suatu tempat bagi para pihak yang tidak puas atas adanya putusan hakim yang dianggap tidak memenuhi rasa keadilan, karena hakim itu juga seorang manusia yang bisa secara tidak sengaja melakukan kesalahan yang dapat menimbulkan salah mengambil keputusan atau memihak kepada salah satu pihak. ${ }^{7}$

\section{Macam-macam Upaya Hukum}

Adapun jenis-jenis upaya hukum dalam Hukum Acara Perdata dibagi menjadi 2 (dua) jenis yaitu:

1) Upaya hukum biasa, adalah upaya hukum yang dipergunakan bagi putusan yang belum memiliki kekuatan hukum tetap yang terdiri dari: (a). Perlawanan (verzet), diatur dalam Pasal 129 ayat (1), Pasal 196, Pasal 197 HIR; (b). Banding, diatur dalam Pasal 21 ayat (1) UU No. 4 Tahun 2004 tentang Kekuasaan Kehakiman, (c). Kasasi, diatur dalam Pasal 30 UU No. 14 Tahun 1985 tentang Mahkamah Agung, dan;

2) Upaya hukum luar biasa, adalah suatu upaya hukum dilakukan atas putusan yang telah berkekuatan hukum tetap (inracht van gewijsde).dan upaya hukum ini dalam asasnya tidaklah menangguhkan pelaksanaan eksekusi. Upaya hukum luar biasa terdiri dari: (a). Perlawanan pihak ketiga (denden verzet) terhadap sita eksekutorial (vide Yurisprudensi Putusan Mahkamah Agung Nomor 306 K/ Sip/ 1962 tanggal 21 Oktober 1962; (b). Peninjauan kembali (request civil), diatur dalam Pasal 66,

${ }^{3}$ Soerjono Soekanto dan Sri Mamudji, Penelitian Hukum Normatif, Suatu Tinjauan Singkat, (Jakarta: Raja Grafindo Persada, 2011), 12.

${ }^{4}$ Peter Mahmud Marzuki, Penelitian Hukum, (Jakarta: Kencana. 2008), 29.

5 Peter Mahmud Marzuki, Penelitian Hukum, (Jakarta: Kencana, 2009), 95.

${ }^{6}$ M. Endriyo Susila et al, Buku Pedoman Penulisan Hukum, (Yogyakarta: Fakultas Hukum Universitas Muhammadiyah Yogyakarta, 2007), 40-41.

7 Sudikno Mertokusumo, Hukum Acara Perdata Indonesia, (Yogyakarta: Penerbit Liberty, 2009), 234. 
Pasal 67, Pasal 71, Pasal 72 UU No. 14 tahun 1985 tentang Mahkamah Agung jo Peraturan Mahkamah Agung Nomor 1 tahun 1982.

\section{Jaminan}

Menurut ketentuan Pasal 2 ayat (1) Surat Keputusan Direksi Bank Indonesia, Jaminan adalah suatu keyakinan atas kesanggupan debitor untuk melunasi kredit sesuai dengan yang diperjanjikan. Di dalam Seminar Badan Pembinaan Hukum Nasional yang diselenggarakan di Yogyakarta, dari tanggal 20-30 Juli 1977

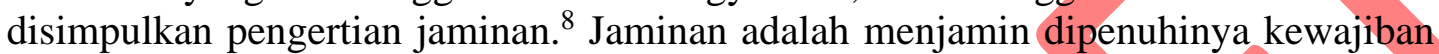
yang dapat dinilai dengan uang yang timbul dari suatu perikatan hukum. Oleh karena itu, hukum jaminan erat sekali dengan hukum benda. ${ }^{9}$

\section{Hak Tanggungan}

1. Pengertian

Pengertian Hak Tanggungan berdasarkan Pasal 1 Angka 1 Undang-Undang Nomor 4 Tahun 1996 Tentang Hak Tanggungan adalah hak jaminan yang dibebankan pada hak atas tanah sebagaimana dimaksud dalam Undang - Undang Nomor 5 Tahun 1960 tentang Peraturan Dasar Pokok-Pokok Agraria, berikut atau tidak berikut bendabenda lain yang merupakan satu kesatuan dengan tanah itu, untuk pelunasan utang tertentu, yang memberikan kedudukan yang diutamakan kepada kreditor tertentu terhadap kreditor-kreditor yang lain. ${ }^{10}$

\section{Pembebanan Hak Tanggungan}

Pembebanan Hak Tanggungan terdapat di dalam Asas-asas dalam Hak Tanggungan yaitu dalam Undang-Undang Nomor 4 Tahun 1996 Tentang Hak Tanggungan ini ada beberapa hal yang perlu diperhatikan yang membedakan Hak Tanggungan dengan lembaga jaminan yang ada sebelum dikeluarkannya undang-undang tersebut. Salah satu diantaranya ialah pencantuman benda-benda yang berkaitan dengan tanah dalam pembebanannya. Sebagaimana diketahui Hukum Tanah Nasional didasarkan pada hukum adat yang menggunakan asas pemisahan horisontal, benda-benda yang merupakan satu kesatuan dengan tanah menurut hukum bukan merupakan bagian dari tanah yang bersangkutan. Oleh karena itu setiap perbuatan hukum mengenai hak-hak atas tanah, tidak dengan sendirinya meliputi benda-benda tersebut. Namun demikian penerapan asas-asas hukum adat tidaklah mutlak, melainkan selalu memperhatikan dan disesuaikan dengan perkembangan kenyataan dan kebutuhan masyarakat yang dihadapinya. Pembebanan Hak Tanggungan atas tanah dimungkinkan pula meliputi benda-benda yang ada di atasnya sepanjang benda-benda tersebut merupakan satu kesatuan dengan tanah yang bersangkutan. Pasal 4 ayat (4) dan ayat (5) UndangUndang Nomor 4 Tahun 1996 Tentang Hak Tanggungan menentukan bahwa obyek Hak Tanggungan dapat meliputi bangunan, tanaman, dan hasil karya yang merupakan satu kesatuan dengan tanah. Hak Tanggungan pada dasarnya adalah Hak Tanggungan

\footnotetext{
${ }^{8}$ Pasal 2 ayat (1) Surat Keputusan Direksi Bank Indonesia No. 23/69/KEP/DIR tentang Jaminan Pemberian Kredit.

${ }^{9}$ Salim H.S, Perkembangan Hukum Jaminan Di Indonesia, (Jakarta: PT. Raja Grafindo Persada, 2004), 22.

${ }^{10}$ Purwahid Patrik dan Kashadi, Hukum Jaminan Edisi Revisi Dengan Undang-Undang Nomor 4 Tahun 1996 Tentang Hak Tanggungan, (Semarang: Fakultas Hukum Universitas Diponegoro, 2006), 52.
} 
yang dibebankan atas tanah. Hal ini sesuai dengan asas pemisahan horisontal yang dianut hukum tanah nasional yang didasarkan pada hukum adat. ${ }^{11}$

Pembebanan Hak Tanggungan merupakan suatu proses yang terdiri atas 2 tahap kegiatan, yaitu: ${ }^{12}$

a. Tahap Pemberian Hak Tanggungan, yaitu dengan dibuatnya APHT oleh Pejabat Pembuat Akta Tanah, yang didahului dengan perjanjian utang-piutang yang dijamin;

b. Tahap Pendaftaran oleh Kantor Pertanahan, yang merupakan saat lahirnya Hak Tanggungan yang dibebankan.

3. Dasar Hukum Hak Tanggungan

Lahirnya undang-undang tentang hak tanggungan karena adanya perintah dalam pasal 51 UUPA. Pasal 51 UUPA berbunyi "Hak Tanggungan yang dapat dibebankan pada hak milik, hak guna usaha, dan hak guna bangunan tersebut dalam pasal 25, pasal 33, dan pasal 39 diatur dalam undang-undang. Tetapi dalam pasal 57 UUPA, disebutkan bahwa selama undang-undang hak tanggungan belum terbentuk, maka digunakan ketentuan tentang hipotek sebagaimana yang diatur dalam KUHPerdata dan Credietverband. Perintah pasal 51 UUPA baru terwujud setelah menunggu selama 36 Tahun. Undang-Undang Nomor 4 Tahun 1996 ditetapkan pada tanggal 9 April 1996. Undang-undang tersebut terdiri atas 11 bab, dan 31 Pasal.

4. Asas-asas Hak Tanggungan

Dalam Hak Tanggungan ada beberapa asas yang membedakan Hak Tanggungan dari jenis dan bentuk jaminan-jaminan utang yang lain. Menurut Kashadi dalam buku Hak Tanggungan Dan Jaminan Fidusia, asas-asas tersebut adalah:

1) Asas spesialitas Asas spesialitas ini dapat diketahui dari penjelasan Pasal 11 ayat

(1) UUHT yang menyatakan bahwa ketentuan ini menetapkan isi yang sifatnya wajib untuk sahnya Akta Pemberian Hak Tanggungan (APHT). Tidak dicantumkannya secara lengkap hal-hal yang disebut pada ayat ini dalam APHT mengakibatkan akta yang bersangkutan batal demi hukum. Ketentuan ini dimaksudkan memenuhi asas spesialitas dari Hak Tanggungan, baik mengenai subyek, obyek maupun hutang yang dijamin.

2) Asas publisitas Asas publisitas ini dapat diketahui dari Pasal 13 ayat (1) UUHT yang menyatakan bahwa pemberian Hak Tanggungan wajib didaftarkan pada Kantor Pertanahan. Dengan didaftarkannya Hak Tanggungan merupakan syarat mutlak untuk lahirnya Hak Tanggungan tersebut dan mengikatnya Hak Tanggungan terhadap pihak ketiga.

\section{Subjek Hak Tanggungan}

Subjek hak tanggungan adalah:

1) Pemberi hak tanggungan Dalam Pasal 8 ayat (1) dan (2) Undang-Undang Hak Tanggungan dijelaskan, pemberi hak tanggungan adalah orang perseorangan atau badan hukum yang mempunyai kewenangan untuk melakukan perbuatan hukum terhadap objek hak tanggungan yang bersangkutan.

2) Pemegang hak tanggungan Berdasarkan Pasal 9 ayat (1) Undang-Undang Hak Tanggungan: Pemegang hak tanggungan adalah orang perorangan atau badan hukum yang berkedudukan sebagai pihak yang berpiutang.

\section{Objek Hak Tanggungan}

11 Sudaryanto. W, Pokok-Pokok Kebijakan Undang-Undang Hak Tanggungan, Seminar Nasional Undang-Undang Nomor 4 Tahun 1996 Tentang Hak Tanggungan tanggal 10 April 1996, Fakultas Hukum Universitas Trisakti, Jakarta, 10.

12 Purwahid Patrik dan Kashadi, Op. cit, 62. 
Objek Hak Tanggungan menurut Pasal 4 ayat (1) dan ayat (2) dan Pasal 27 Undang-Undang Nomor 4 Tahun 1996 Tentang Hak Tanggungan yaitu :

1) Pasal 4 ayat (1) Undang-Undang Nomor 4 Tahun 1996 Tentang Hak Tanggungan Hak atas tanah yang dapat dibebani Hak Tanggungan adalah: a. Hak Milik b. Hak Guna Usaha c. Hak Guna Bangunan.

2) Pasal 4 ayat (2) Undang-Undang Nomor 4 Tahun 1996 Tentang Hak Tanggungan Selain hak-hak atas tanah sebagaimana dimaksud pada ayat (1), Hak Pakai atas tanah Negara yang menurut ketentuan yang berlaku wajib didaftar dan menurut sifatnya dapat dipindahtangankan dapat juga dibebani Hak Tanggungan.

3) Pasal 27 Undang - Undang Nomor 4 Tahun 1996 Tentang Hak Tanggungan Ketentuan Undang-Undang ini berlaku juga terhadap pembebanan hak jaminan atas Rumah Susun dan Hak Milik Atas Satuan Rumah Susun.

\section{Pengalihan Hutang (Cessie)}

Cessie adalah cara pengalihan dan atau penyerahan piutang atas nama sebagaimana yang dimaksud di dalam Pasal 613 Kitab UndangUndang Hukum Perdata (KUHPerdata). ${ }^{13}$ Piutang yang timbul berdasarkan kegiatan pemberian kredit yang dilakukan oleh Bank merupakan suatu tagihan atas nama. Tagihan itu melibatkan dua pihak yaitu kreditur dan debitur. Adanya suatu tagihan disebabkan karena debitur tertentu berhutang kepada kreditur tertentu, yang kemudian dialihkan oleh kreditur tersebut kepada kreditur lainnya. Seperti yang tercantum dalam pasal 613 ayat (2) Kitab Undang-Undang Hukum Perdata (KUHPerdata) mengenai penyerahan yaitu penyerahan berdasarkan atas suatu peristiwa perdata untuk memindahkan hak milik, dilakukan oleh seorang yang berhak berbuat bebas (mengambil tindakan pemilikan) terhadap kebendaan tersebut. ${ }^{14}$

Dalam penyerahan piutang atas nama dengan cara cessie terdapat tiga pihak yaitu Cedent sebagai kreditur lama yang memiliki tagihan piutang atas nama, kemudian Cessionaris sebagai kreditur baru yang menerima pengalihan piutang atas nama dan Cessus sebagai debitur dalam hal ini hanya sebagai pihak yang menerima pemberitahuan atau memberikan persetujuan atas perjanjian cessie yang dibuat antara cedent dengan Cessionaris. Karena Cessie merupakan bentuk penyerahan piutang atas nama, maka untuk terjadinya penyerahan harus didasarkan adanya alas hak (Rechttitel) yang merupakan hubungan perdata yang mendasari adanya pengalihan hak. Alas hak tersebut terjadi karena adanya hubungan obligatoir atau hubungan yang mengalihkan hak atas piutang tersebut. Pada umumnya hubungan obligatoir tersebut berupa perjanjian jual-beli piutang atau tagihan. Dengan demikian terdapat dua perbuatan hukum dalam penyerahan piutang atas nama yaitu perjanjian jual-beli yang merupakan alas haknya dan perjanjian cessie sebagai bentuk penyerahan piutang atas nama. ${ }^{15}$

\section{Pembebanan Hak Tanggungan}

Hak Tanggungan adalah hak jaminan yang dibebankan pada hak atas tanah sebagaimana dimaksud dalam Undang-Undang Nomor 5 Tahun 1960 tentang Peraturan Dasar Pokok-Pokok Agraria, berikut atau tidak berikut benda-benda lain yang merupakan satu kesatuan dengan tanah itu, untuk pelunasan utang tertentu, yang

${ }^{13}$ Soeharnoko dan Endah Hartati, Doktrin Subrogasi, Novasi dan Cessie, (Jakarta: Kencana, 2008), cet. III, 101.

${ }^{14}$ Rachmad Setiawan dan J.Satrio, Penjelasan Hukum Tentang Cessie, (Jakarta: PT Gramedia, 2010), 1 .

15 Akhmad Budi Cahyono, Cessie Sebagai Bentuk Pengalihan Piutang Atas Nama, Lex Jurnalica/ Vol. 2 /No.1/ Desember 2004, 16. 
memberikan kedudukan yang diutamakan kepada kreditur tertentu terhadap krediturkreditur lain. ${ }^{16}$ Dalam perjanjian utang-piutang, konsumen (debitur) disyaratkan untuk memberikan jaminan kebendaan yang memadai. Pada asasnya tidak ada kredit yang tidak mengandung jaminan. ${ }^{17}$

Hak atas tanah yang dapat menjadi obyek Hak Tanggungan haruslah hak atas tanah menurut Undang-Undang Pokok Agraria yang sudah terdaftar dan sifatnya dapat dipindahtangankan. Hak atas tanah yang dapat dijadikan obyek Hak Tanggungan adalah: 18

1. Hak Milik;

2. Hak Guna Bangunan;

3. Hak Guna Usaha;

4. Hak Pakai atas tanah negara yang menurut ketentuan wajib di daftar dan menurut sifatnya dapat dialihkan.

Ketentuan tersebut menunjukan bahwa Hak Tanggungan pada prinsipnya hanya dapat dibebankan pada tanah-tanah yang telah terdaftar menurut UUPA dan Peraturan Pemerintah Nomor 24 Tahun 1997 tentang Pendaftaran Tanah. Landasan dasar penerapan hak tanggungan dimana hak tanggungan dapat dijadikan sebagai jaminan terhadap benda tidak bergerak baik berupa tanah, tanah dan bangunan yang melekat padanya atau bangunan yang berdiri atas tanah tersebut terpisah dari dari status hak atas tanahnya. Bangunan yang terpisah dari hak atas tanah yang dapat dijadikan hak tanggungan apabila bangunan tersebut didirikan diatas status tanah hak guna bangunan, hak pakai, hak guna usaha dan hak sewa. Apabila bangunan tersebut didirikan atas hak milik maka bangunan tidak dapat dipisahkan dari tanahnya sebagai jaminan perlunasan hutang. ${ }^{19}$

Pemberi Hak Tanggungan adalah orang perseorangan atau badan hukum yang mempunyai kewenangan untuk melakukan perbuatan hukum terhadap objek Hak Tanggungan yang bersangkutan. Dengan demikian, karena objek Hak Tanggungan adalah Hak Milik, Hak Guna Usaha, Hak Guna Bangunan dan Hak Pakai atas tanah Negara. ${ }^{20}$ Sedangkan pemegang Hak Tanggungan adalah orang perseorangan atau badan hukum yang berkedudukan sebagai pihak yang berpiutang. Orang itu bisa orang asing dan bisa juga badan hukum asing, baik yang berkedudukan di Indonesia ataupun di luar negeri, sepanjang kredit yang bersangkutan dipergunakan untuk kepentingan pembangunan di wilayah Negara Republik Indonesia. ${ }^{21}$ Ketentuan dua pasal tersebut dapat disimpulkan bahwa yang menjadi subjek hukum dalam hak tanggungan adalah subjek hukum yang terkait dengan perjanjian pemberi hak tanggungan. Di dalam suatu perjanjian hak tanggungan ada dua pihak yang mengikatkan diri, yaitu sebagai berikut: 1) Pemberi Hak Tanggungan, yaitu orang atau pihak yang menjaminkan objek hak tanggungan (debitor); 2) Pemegang Hak Tanggungan, yaitu orang atau pihak yang menerima Hak Tanggungan sebagai jaminan dari pihutang yang diberikannya.

Subjek Hak Tanggungan selain Warga Negara Indonesia adalah Warga Negara Asing. Dengan ditetapkannya hak pakai atas tanah negara sebagai salah satu objek hak

${ }^{16}$ Pasal 1 ayat (1) Undang - Undang Nomor 4 tahun 1996 tentang Hak Tanggungan.

17 J. Satrio, Parate Eksekusi Sebagai Sarana Mengatasi Kredit Macet, (Bandung: Citra Aditya Bhakti, Bandung, 1993), 5.

${ }^{18}$ Lihat Pasal 4 ayat (1) dan (2) UUHT.

${ }^{19}$ Djuhaendah Hasan, Lembaga Jaminan Kebendaan Bagi Tanah dan Benda Lain Yang Melekat Pada Tanah Dalam Konsepsi Penerapan Asas Pemisahan Horisontal, (Bandung: PT. Citra Aditya Bakti, 1996), 62.

${ }^{20}$ Lihat Pasal 8 UUHT.

${ }^{21}$ Lihat Pasal 9 UUHT. 
tanggungan, bagi warga negara asing juga dimungkinkan untuk dapat menjadi subjek hak tanggungan apabila memenuhi syarat. Sebagai pemegang hak tanggungan yang berstatus Warga Negara Indonesia, badan hukum Indonesia, Warga Negara Asing atau badan hukum asing tidak disyaratkan harus berkedudukan di Indonesia. Oleh karena itu jika perjanjian kreditnya dibuat di luar negeri dan pihak pemberi kreditnya orang asing atau badan hukum asing yang berdomisili di luar negeri dapat pula menjadi pemegang Hak Tanggungan, sepanjang perjanjian kredit yang bersangkutan dipergunakan untuk kepentingan pembangunan di wilayah Republik Indonesia. ${ }^{22}$

Untuk dapat dijadikan jaminan utang dengan dibebani hak jaminan atas tanah, termasuk Hak Tanggungan, benda yang bersangkutan harus memenuhi syarat-syarat yang tersurat dalam Undang-undang Hak Tanggungan. ${ }^{23}$ UUHT juga membuka kemungkinan membebankan tanah berikut atau tidak berikut bangunan atau tanaman yang ada diatasnya. Namun selain hak-hak tersebut, ternyata memperluas hak-hak tanah yang dapat dijadikan jaminan hutang selain hak-hak atas tanah sebagaimana yang dimaksud dalam Pasal 4 ayat (1) UUHT. $^{24}$

Pada dasarnya pemberian Hak Tanggungan hanya dimungkinkan jika dibuat dalam bentuk perjanjian, ${ }^{25}$ maka pemberian Hak Tanggungan tersebut harus memenuhi syarat sahnya perjanjian seperti yang ditentukan dalam Pasal $1320 \mathrm{KUH}$ Perdata, dan salah satu syaratnya adalah kecakapan untuk membuat suatu perikatan. Kecakapan bertindak dalam banyak hal berhubungan dengan masalah kewenangan bertindak dalam hukum, dimana kecakapan berkaitan dengan masalah kemampuan untuk melakukan suatu tindakan/perbuatan hukum dan kewenangan berkaitan dengan kapasitas subjek hukum dalam melakukan tindakan atau perbuatan hukum. ${ }^{26}$

Perjanjian Hak Tanggungan kewenangan pemberi Hak Tanggungan berkaitan dengan kewenangan untuk melakukan perbuatan hukum atas objek Hak Tanggungan, karena pemberi Hak Tanggungan adalah pemilik persil yang dengan sepakatnya dibebani dengan Hak Tanggungan sampai sejumlah hutang tertentu untuk menjamin suatu perikatan atau hutang. Sehingga yang dapat menjadi pemberi Hak Tanggungan adalah pemilik hak atas tanah yang dijaminkan. ${ }^{27}$ Jaminan yang banyak diminta oleh bank adalah jaminan berupa hak atas tanah karena didasarkan pada pertimbangan bahwa tanah pada umumnya mudah dijual, harganya terus meningkat, mempunyai tanda bukti hak, sulit digelapkan dan dapat dibebani dengan Hak Tanggungan yang memberikan hak istimewa kepada kreditor. ${ }^{28}$ Agar perlindungan hukum bagi kreditor pemegang Hak Tanggungan dapat dicapai maka pembebanan Hak Tanggungan harus memenuhi persyaratan dan dilakukan sesuai dengan ketentuan hukum yang berlaku.

Pemberian hak tanggungan dibuktikan dengan akta pemberian hak tanggungan (APHT). Bagi pemegang hak tanggungan tidak ada persyaratan khusus, ia bisa orang perseorangan, bisa badan hukum, bisa orang asing, bisa badan hukum asing baik yang berkedudukan di Indonesia ataupun di luar negeri, sepanjang kredit yang bersangkutan

${ }^{22}$ Lihat Pasal 10 ayat (1) UUHT.

${ }^{23}$ Lihat penjelasan umum angka 5 dan Pasal 4 ayat (1) UUHT.

${ }^{24}$ Lihat Pasal 4 ayat (2) UUHT.

${ }^{25}$ Pasal 10 ayat (1) UUHT yang menyatakan: Pemberian Hak Tanggungan didahului dengan janji untuk memberikan Hak Tanggungan sebagai jaminan pelunasan utang tertentu, yang dituangkan didalam dan merupakan bagian tak terpisahkan dari perjanjian utang piutang yang bersangkutan atau perjanjian lainnya yang menimbulkan utang tersebut.

${ }^{26}$ Kartini Muljadi, Gunawan Widjaja, Seri Hukum Harta Kekayaan: Hak Tanggungan, (Jakarta, Prenada Media, 2004), 52.

27 J. Satrio, Hukum Jaminan, Hak Jaminan Kebendaan Hak Tanggungan, (Bandung: PT. Citra Aditya, 1997), 245.

${ }^{28}$ Adrian Sutedi, Hukum Hak Tanggungan, (Jakarta: Sinar Grafika, 2010), 7. 
dipergunakan untuk kepentingan pembangunan di wilayah Negara Republik Indonesia. ${ }^{29}$ Pelaksanaan pembebanan Hak Tanggungan dilaksanakan melalui dua tahap kegiatan, yaitu tahap pemberian Hak Tanggungan yang dilakukan dengan perjanjian tertulis, yang dituangkan dalam Akta Pemberian Hak Tanggungan (APHT) dihadapan Pejabat Pembuat Akta Tanah ${ }^{30}$ dan tahap dilakukannya pendaftaran Hak Tanggungan di Kantor Pertanahan. ${ }^{31}$

Menurut ketentuan Pasal 10 ayat (2) UUHT pemberian Hak Tanggungan yang wajib dihadiri oleh pemberi Hak Tanggungan, pemegang Hak Tanggungan dan dua orang saksi, dilakukan dengan pembuatan Akta Pemberian Hak Tanggungan (APHT) yang dibuat oleh Pejabat Pembuat Akta Tanah (PPAT) sesuai peraturan Perundangundangan yang berlaku. APHT yang dibuat oleh PPAT tersebut merupakan akta otentik (Penjelasan Umum angka 7 UUHT). Dalam Pasal 11 ayat (1) UUHT disebutkan hal-hal yang wajib dicantumkan dalam APHT, yaitu: ${ }^{32}$

a. Nama dan identitas pemberi dan pemegang Hak Tanggungan;

b. Domisili pihak-pihak sebagaimana dimaksud pada angka 1, dana pabila di antara mereka ada yang berdomisili di luar Indonesia, baginya harus pula dicantumkan suatu domisili pilihan di Indonesia. Penunjukan secara jelas hutang atau hutanghutang yang dijamin pelunasannya dengan Hak Tanggungan dan meliputi juga nama dan identitas debitur yang bersangkutan;

c. Nilai tanggungan;

d. Uraian yang jelas mengenai objek Hak Tanggungan.

Selanjutnya APHT dan Blangko permohonan pemberian Hak Tanggungan didaftarkan ke Badan Pertanahan Nasional (BPN) melalui bagian pendaftaran tanah untuk penerbitan sertifikat Hak Tanggungan oleh BPN. Pada umumnya pelaksanaan pembebanan Hak Tanggungan atas tanah biasanya didahului dengan adanya perjanjian pokok yaitu perjanjian utang-piutang atau disebut juga dengan perjanjian kredit. Adapun tahap-tahap yang harus dilakukan dalam pelaksanaan perjanjian kredit atau biasa disebut juga dengan akad kredit di kantor Notaris-PPAT diantaranya sebagai berikut:

a. Bank mengirimkan order terlebih dahulu kepada Notaris-PPAT setempat untuk meminta dibuatkannya dan dipersiapkan segala akta dan berkas-berkas yang diperlukan dalam pembuatan Perjanjian Kredit.

b. Setelah menerima order dan berkas-berkas yang dibutuhkan, seorang Notaris segera mempersiapkan akta dan melakukan pengecekan sertifikat hak milik yang digunakan sebagai jaminan kredit tersebut terlebih dahulu ke kantor BPN setempat.

c. Apabila hasil pengecekan sudah keluar dari kantor BPN dan akta-akta yang diinginkan bank telah disiapkan oleh Notaris-PPAT maka Notaris harus memberitahukan kepada bank untuk segera dilaksanakan akad kredit dengan mengadakan janji (appointment) tentang waktu penandatanganan perjanjian kredit oleh kedua belah pihak yang dalam hal ini adalah debitur dan kreditur akan dilakukan di hadapan Notaris-PPAT.

${ }^{29}$ Menurut pasal 23 huruf (f) PP Nomor 24 tahun 1997 tentang Pendaftaran Tanah.

${ }^{30}$ Akta Pemberian Hak Tanggungan dibuat dalam perjanjian utang piutang untuk dicantumkan “janji” Pemberian Hak Tanggungan sebagai jaminan pelunasan utang tertentu, berhubung sifat Hak Tanggungan sebagai perjanjian accessoir. Menurut penjelasan atas Pasal 10 ayat (1) UUHT, pemberiah Hak Tanggungan tersebut karenanya haruslah merupakan perjanjian yang menimbulkan hubungan hukum utang piutang yang dijamin pelunasannya.

${ }^{31}$ Rachmadi Usman, Hukum Jaminan Keperdataan, (Jakarta: Sinar Grafika, 2008), 397-401.

${ }^{32}$ Adrian Sutedi, op., cit, 91. 
d. Sesuai dengan kesepakatan tanggal atau hari dan jam yang ditentukan, para pihak wajib hadir di hadapan Notaris-PPAT untuk segera dilakukan akad kredit. Adapun tahap-tahap yang harus dilakukan dalam akad kredit sebagai berikut:

1) Akta-akta harus dibacakan terlebih dahulu serta dijelaskan isi dan maksudnya kepada para pihak oleh Notaris.

2) Apabila para pihak telah menyatakan pemahamannya dan persetujuannya tentang isi akta, maka langsung diikuti dengan penandatanganan oleh para pihak, dua orang saksi dan Notaris-PPAT itu sendiri.

e. Apabila akta-akta sudah ditandatangani, Notaris-PPAT akan mengeluarkan salinannya serta menindaklanjuti dengan mendaftarkan Hak Tanggungannya ke kantor BPN.

Pembebanan Hak Tanggungan ini terdapat dua perbedaan yaitu pembebanan yang bisa langsung dibuat APHT dimana sertifikatnya sudah atas nama debitur/ pemberi jaminan Hak Tanggungannya sendrir dan pembebanan Hak Tanggungan yang tidak bisa langsung dibuat APHT dengan kata lain harus didahului denga Surat Kuasa Membebankan Hak Tanggungan (SKMHT). ${ }^{33}$

Keberadaan Hak Tanggungan sebenarnya ditentukan melalui pemenuhan tata cara pembebanannya yang meliputi dua tahap, yaitu:

a. Tahap Pemberian Hak Tanggungan

Untuk keperluan pembebanan Hak Tanggungan, pertama-tama debitur harus menyerahkan kepada bank sertifikat hak atas tanah berupa Hak Milik (HM), Hak Guna Usaha (HGU), Hak Guna Bangunan (HGU), Hak Pakai atas tanah Negara yang akan dibebani Hak Tanggungan. Sertifikat hak atas tanah tersebut dapat atas nama debitur sendiri atau atas nama pihak ketiga.

b. Tahap Pendaftaran Hak Tanggungan

Pemberian Hak Tanggungan menurut Pasal 13 ayat (1) UUHT, wajib didaftarkan pada Kantor Pertanahan. Sebelum melakukan pendaftaran ke kantor pertanahan, adapun syarat-syarat yang harus dilengkapi dengan waktu tujuh hari, serta tarif untuk pendaftaran atau pemasangan Hak Tanggungan sebagai berikut:

1) Sertifikat asli;

2) Akta Pemberian Hak Tanggungan (APHT);

3) Salinan APHT yang sudah diparaf oleh PPAT yang bersangkutan untuk disahkan sebagai salinan oleh Kepala Kantor untuk pembuatan sertifikat Hak Tanggungan;

4) Fotocopy KTP pemberi Hak Tanggungan (debitur) atau Akta Pendirian Badan Hukum, Penerima Hak Tanggungan (kreditur) dan/atau kuasanya yang telah dicocokkan dengan aslinya oleh petugas loket;

5) Surat Kuasa Membebankan Hak Tanggungan (SKMHT) apabila Pemberi Hak Tanggungan melalui kuasa. ${ }^{34}$

\footnotetext{
${ }^{33}$ Surat Kuasa Membebankan Hak Tanggungan atau yang disingkat dengan SKMHT adalah kuasa yang diberikan oleh pemberi Hak Tanggungan sebagai pemberi kuasa kepada penerima kuasa khusus untuk membebankan suatu benda dengan Hak Tanggungan. Lihat Mariam Darus Badrulzaman, Buku II Kompilasi Hukum Jaminan, (Bandung: Mandar Maju, 2004), 76.

${ }^{34}$ Lihat Pasal 15 ayat (1) UUHT: SKMHT wajib dibuat dengan akta notariil atau akta PPAT. Adapun alasan pembuatan SKMHT dengan akta notariil yaitu dilihat dari kedudukannya dan objeknya tidak terbatas/nasional, karena letak tanahnya di luar tempat kedudukan PPAT-nya maka itulah alasan mengapa tidak dibuat dengan akta PPAT. Perbedaan SKMHT notariil dengan SKMHT PPAT dilihat dari Surat Keputusan Jabatannya yang disebutkan pada komparisi akta SKMHT dan dari cap/stempel jabatan.
} 


\section{Pengalihan Piutang (Cessie) kepada Kreditur Baru (Cessionaris)}

Cessie adalah penyerahan piutang ${ }^{35}$ atas nama dan barang barang lain tidak bertubuh, dilakukan dengan jalan membuat akta (otentik ${ }^{36}$ atau dibawah tangan), yang disebut akta cessie yang melimpahkan hak hak atas barang barang itu kepada orang lain. Penyerahan itu tidak aka ada akibatnya bagi yang berhutang sebelum penyerahan itu diberitahukan kepadanya, Disetujui secara tertulis, dan diakuinya. ${ }^{37}$

Dalam tagihan atas nama, debitur mengetahui dengan pasti siapa krediturnya. Salah satu ciri khas yang dimiliki oleh suatu tagihan atas nama adalah bahwa tagihan atas nama tidak memiliki wujud. Apabila dibuatkan suatu surat hutang, maka surat hutang hanya berlaku sebagai alat bukti saja. Hal ini disebabkan karena adanya surat hutang dalam bentuk apapun bukan merupakan sesuatu yang penting dari suatu tagihan atas nama. Dengan demikian maka, jika tagihan atas nama dituangkan dalam bentuk surat hutang, maka penyerahan secara fisik surat hutang itu belum mengalihkan hak tagih yang dibuktikan dengan surat yang bersangkutan. Untuk mengalihkan tagihan atas nama, dibutuhkan akta penyerahan tagihan atas nama yang dalam doktrin dan yurisprudensi disebut sebagai akta cessie.

Notaris adalah Pejabat Umum yang berwenang untuk membuat Akta Otentik mengenai semua perbuatan, perjanjian, dan ketetapan yang diharuskan oleh peraturan perundang-undangan dan/atau yang dikehendaki oleh yang berkepentingan untuk dinyatakan dalam akta otentik, menjamin kepastian tanggal pembuatan akta, menyimpan akta, memberikan grosse salinan dan kutipan akta, semuanya itu sepanjang pembuatan akta-akta itu tidak juga ditugaskan atau dikecualikan kepada pejabat lain atau orang lain yang ditetapkan oleh undang-undang. ${ }^{38}$ Notaris dengan jelas telah diberikan wewenang sepenuhnya oleh Negara melalui Undang-Undang untuk dapat membuat akta otentik terhadap perbuatan hukum mengenai peralihan piutang melalui proses cessie. Dengan begitu, pembuatan akta cessie oleh Notaris merupakan kewenangan umum yang dimiliki oleh Notaris. Dengan adanya akta cessie dari Notaris, dapat dijadikan dasar atau bukti bahwa objek tersebut telah beralih kepada kreditur baru, namun akta tersebut tidak dapat dijadikan dasar untuk proses balik nama sertipikat di Badan Pertanahan Nasional. Akta yang dapat membantu peralihan balik nama Sertipikat adalah akta PPAT dan bukan akta Noatriil, hal ini berlaku bagi cessie. ${ }^{39}$

${ }^{35}$ Piutang atau tagihan atas nama. Dalam tagihan atas nama, debitur mengetahui dengan pasti siapa krediturnya. Hak tagih yang timbul dari adanya hubungan hukum pinjam meminjam uang antara pihak yang meminjamkan (si berpiutang) dengan pihak yang meminjam (si berhutang) atau dari suatu kegiatan penyaluran fasilitas kredit antara Bank atau lembaga keuangan non-bank selaku kreditur dengan debiturnya. Piutang atau hak tagih yang timbul dari hubngan hukum pinjam meminjam uang atau dari kegiatan penyaluran kredit bank tersebut dapat dialihkan kepada pihak ketiga, dengan cara cessie. Lihat Pasal 613 KUHPerdata.

Akta otentik menurut ketentuan Pasal 1868 Kitab Undang-Undang Hukum Perdata (KUHPerdata) yaitu Suatu akta otentik ialah suatu akta yang di dalam bentuk yang ditentukan oleh undang-undang, dibuat oleh atau dihadapan pegawai-pegawai umum yang berkuasa untuk itu di tempat di mana akta dibuatnya. Lihat Abdul Wahid, Elya Kusuma Dewi, Sarip, Kekuatan Alat Bukti Akta Otentik Terhadap Akta Pejabat Pembuat Akta Tanah (PPAT) Berdasarkan Peraturan Pemerintah Nomor 24 Tahun 2016 Juncto Pasal 1868 KUHPerdata, Jurnal Mahkamah: Jurnal Kajian Hukum Islam, Vol. 4, No. 2, Desember 2019, Department of Family Law (Al-Ahwal Al-Syakhsiyyah) Faculty of Shariah and Islamic Economics IAIN Syekh Nurjati Cirebon, 209.

${ }^{37}$ Munir Fuady, Hukum Tentang Pembiayaan, cet IV. (Bandung Citra Aditya Bakti, 2006), 74.

${ }^{38}$ Pasal 15ayat (1) Undang-Undang Republik Indonesia Nomor 2 Tahun 2014 Tentang Perubahan Atas Undang-Undang Nomor 30 Tahun 2004 Tentang Jabatan Notaris.

${ }^{39}$ Lihat Pasal 620 KUHPerdata: Dengan mengindahkan ketentuan-ketentuan yang tercanturn dalam tiga pasal yang lalu, pengumuman termaksud di atas dilakukan dengan memindahkan salinan otentik yang lengkap dari akta tersebut atau surat keputusan Hakim ke kantor penyimpan hipotek di lingkungan tempat barang tak bergerak yang harus diserahkan itu berada, dan dengan mendaftarkan salinan ini dalam daftar yang telah ditentukan. Bersama dengan itu, orang yang bersangkutan harus menyampaikan juga salinan otentik yang kedua 
Pada cessie, hak milik beralih dan dengan dibuatnya akta cessie, maka penyerahan (levering) terhadap atas nama telah selesai. ${ }^{40}$ Adanya proses cessie dilatarbelakangi dengan munculnya suatu perbuatan wanprestasi. Dimana debitur tidak dapat melaksanakan kewajibannya dalam melakukan pembayaran angsuran kredit dan memilih untuk pergi (tidak ada kabar) sehingga membuat kreditur terpaksa harus mengeksekusi obyek jaminan, salah satunya dengan melaluí proses cessie. Langkah ini diambil karena kreditur yang dalam hal ini adalah perbankan mendapatkan dampak negatif dari adanya perbuatan wanprestasi tersebut, yaitu perputaran alur dana bank yang menjadi terhambat. Sehingga untuk menutup kekurangan tersebut, kreditur harus secepatnya mendapatkan dana sesuai dengan jumlah hutang yang belum terbayarkan dari debitur yang melakukan wanprestasi. Barang jaminan cessie yang dialihkan berupa Sertipikat tanah biasanya akan berlanjut dengan proses pengalihan balik nama sertipikat dari nama debitur terdahulu menjadi nama pihak kreditur yang baru (pembeli cessie) guna mendapatkan kepastian hukum, namun proses peralihan ini sudah diluar wewenang pihak Bank lagi. ${ }^{41}$

\section{Dampak Pengalihan Hutang (Cessie) Terhadap Jaminan Hak Tanggungan}

Dalam hal debitur atau pemberi gadai tidak memenuhi kewajiban-kewajiban, kreditur tidak diperkenankan mengalihkan barang yang digadaikan itu menjadi miliknya. Segala persyaratan perjanjian yang bertentangan dengan ketentuan ini adalah batal. ${ }^{42}$ Piutang yang dialihkan di dalam perjanjian cessie itu memberikan hak tagih kepada penerima cessie atas setiap dan selurub jumlah-jumlah uang yang wajib dibayarkan oleh debitur kepada kreditur berdasarkan perjanjian kredit. Pengalihan piutang yang dilakukan oleh bank selaku kreditur tersebut mengakibatkan beralihnya hak tagih atau piutang atas debitur yang bersangkutan kepada pihak ketiga yang kemudian menggantikan kedudukan kreditur lama sebagai kreditur yang baru.

Sehubungan dengan hal tersebut maka adanya suatu perjanjian tertulis, baik itu berupa akta otentik maupun akta di bawah tangan, adalah merupakan sesuatu yang mutlak untuk dipenuhi di dalam melakukan pengalihan piutang atas nama. Namun, keberadaan perjanjian cessie yang dibuat baik secara otentik atau dibawah tangan itu belum akan mengikat dan atau memberikan akibat hukum apapun juga kepada debitur bilamana hal mengenai telah dilakukannya pengalihan piutang secara cessie ini tidak diberitahukan kepada debitur atau secara tertulis tidak diakui atau disetujui olehnya. ${ }^{43}$ Mengenai akibat-akibat wanprestasi ini juga terdapat dalam ketentuan KUHPerdata dalam Pasal1236 dan Pasal 1243. Si berutang adalah wajib memberikan ganti biaya, rugi, dan bunga kepada si berpiutang, apabila ia telah membawa dirinya kedalam keadaan tidak mampu untuk menyerahkan kebendaannya, atau tidak merawat sepatutnya guna menyelamatkannya. ${ }^{44}$

Pengambil alihan piutang bank oleh pihak ketiga bukan berarti hanya piutang saja yang diambil alih, tetapi disertai juga dengan pengambilalihan hak dan kewajiban bank, termasuk beralihnya jaminan utang debitur. Pengalihan piutang secara cessie

atau petikan dari akta atau keputusan hakim, agar penyimpan hipotek mencatat di dalamnya hari pemindahan beserta bagian dan nomor daftar yang bersangkutan.

${ }^{40}$ Feronika Y. Yangin, Analisis Hukum Pengalihan Piutang (Cessie) Kepada Pihak Ketiga Menurut Pasal 613 KUH Perdata, Jurnal Lex Privatum, Vol. IV/No. 5/Juni/2016, 81.

${ }^{41}$ Gita Permata Aulia, Endang Sri Kawuryan, Perlindungan Hukum Terhadap Pembeli Cessie Dalam Melakukan Balik Nama Sertipikat Hak Atas Tanah Dan Bangunan, Jurnal Transparansi Hukum: Volume 1, Nomor 1, Januari 2018, 79-98.

${ }^{42}$ Lihat Pasal 1154 KUHPerdata.

${ }^{43}$ Lihat Pasal 613 KUHPerdata.

${ }^{44}$ Lihat Pasal 1236 KUHPerdata. 
tidak mengakibatkan berakhirnya perikatan yang telah ada yang dibuat antara kreditur dengan debitur. Perikatan yang lama tetap ada dan berlaku serta mengikat debitur maupun kreditur yang menerima pengalihan piutang yang dimaksud. Dengan demikian yang terjadi adalah pengalihan seluruh hak dan kewajiban kreditur berdasarkan perjanjian kredit yang ada kepada pihak ketiga yang selanjutnya menjadi kreditur baru. ${ }^{45}$

Hubungan hukum antara debitur dan kreditur berdasarkan perjanjian kredit yang telah ada sebelumnya tidak menjadi putus, sehingga tidak terjadi hubungan hukum yang baru yang menggantikan hubungan hukum yang lama. Perikatan yang lama tetap ada dan berlaku, serta mengikat debitur maupun kreditur yang menerima pengalihan piutang yang dimaksud. Dengan demikian, yang terjadi adalah pengalihan seluruh hak dan kewajiban kreditur berdasarkan perjanjian kredit yang ada kepada pihak ketiga yang selanjutnya menjadi kreditur baru. ${ }^{46}$

Dengan adanya cessie, akibat hukum yang terpenting adalah sebagai berikut: ${ }^{47}$

1) Piutang beralih dari cedent ke cessionaris;

2) Setelah terjadinya cessie, kedudukan cessionaris menggantikan kedudukan cedent, yang berarti segala hak yang dimiliki oleh cedent terhadap cessus dapat digunakan oleh cessionaris sepenuhnya.

Berdasarkan ketentuan Pasal 16 Undang-undang Nomor 4 Tahun 1996 tentang Hak Tanggungan atas Tanah beserta Benda-benda yang berkaitan dengan Tanah tersebut dan dengan memperhatikan penjelasan pasalnya, maka peralihan hak tanggungan tersebut terjadi karena hukum. Oleh karena itu peralihan hak tanggungan sebagai accessoir dari perjanjian pokok, tidak perlu dibuktikan dengan akta yang dibuat oleh Pejabat Pembuat Akta Tanah. Pencatatan beralihnya hak tanggungan itupun cukup dilakukan di Kantor Pertanahan setempat dengan menyertakan akta pengalihan piutang (cessie) nya sebagai dasar beralihnya suatu piutang kepada kreditur yang baru (cesionaris). Pengalihan piutang (cessie) mengalihkan segala hak, kewajiban serta wewenang dari cedent (kreditur awal) kepada cesionaris (kreditur baru). Pengalihan piutang ini mengakibatkan turut beralihnya segala hak, kewajiban dan wewenang terhadap perjanjian pengikatan jaminannya dalam hal ini hak tanggungan. Apabila hak tanggungan disini dibebankan untuk menjamin hutang kepada satu-satunya kreditur berdasarkan perjanjian kredit, maka pengalihan hak tanggungan disini relatif dapat dilakukan dengan mudah dan cepat karena tidak melibatkan banyak pihak. Akan lebih kompleks apabila jaminan hak tanggungan tersebut digunakan untuk menjamin fasilitas kredit yang diberikan oleh lebih dari satu kreditur seperti yang terjadi pada kredit sindikasi. Jelas karena melibatkan banyak kreditur maka proses peralihan piutang maupun hak tanggungannya akan lebih rumit dan memakan waktu yang lebih lama. ${ }^{48}$

Peralihan hak tanggungan dilakukan oleh kreditur baru di kantor pertanahan di wilayah hukum dimana objek jaminan hak tanggungan itu berada dan terdaftar, dengan membawa dokumendokumen yang berkaitan dengan pengalihan kredit, yaitu identitas

45 David Simatupang, Sengketa Hak Atas Tanah Melalui Akta Cessie (Studi Kasus Putusan Mahkamah Agung NO 308/PK/PDT2016 Jo Kasasi NO 1625 K/PDT/2014), Jurnal Hukum: Hukum Untuk Mengatur Dan Melindungi Masyarakat, Fakultas Hukum Universitas Kristen Indonesia, Volume 6, No. 1 bulan April 2020, 33-41.

46 Rachmad Setiawan dan J. Satrio, Penjelasan Hukum tentang Cessie, (Jakarta: Gramedia, 2010), 47.

${ }^{47} \mathrm{Ibid}, 56$.

${ }^{48}$ Widya Padmasari, Perlindungan Hukum Bagi Para Pihak Dalam Pengalihan Piutang (Cessie) Melalui Akta Notaris, Jurnal Hukum dan Kenotariatan, Volume 2 Nomor 2 Agustus 2018, Pascasarjana UNISMA, 264-275. 
pihak yang mengalihkan (kreditur lama) dan yang menerima pengalihan (kreditur baru), Akta Perjanjian Jual-Beli Piutang dan Pengalihan Hak Atas Tagihan (Cessie) yang dibuat di hadapan Notaris serta dokumen-dokumen milik debitur yang sebelumnya berada di dalam penguasaan kreditur lama. Hal-hal yang kemudian akan dilakukan oleh kantor pertanahan berkaitan dengan pendaftaran peralihan hak tanggungan yaitu dengan melakukan pencatatan pada buku tanah hak tanggungan, buku-buku hak atas tanah yang menjadi objek hak tanggungan dan menyalin catatan tersebut pada sertifikat hak tanggungan dan sertifikat hak atas tanah yang bersangkutan. ${ }^{49}$

Peralihan hak tanggungan baru berlaku dan mengikat kreditur baru adalah sejak tanggal pencatatan pada buku tanah. Adapun tanggal pencatatan pada buku tanah tersebut dilakukan pada tanggal hari ketujuh setelah diterimanya secara lengkap suratsurat yang diperlukan bagi pendaftaran beralihnya hak tanggungan. Namun jika tanggal hari ketujuh itu jatuh pada hari libur, maka pencatatan tersebut dilakukan pada hari kerja berikutnya. Pendaftaran pengalihan hak tanggungan dari kreditur lama kepada kreditur baru atas adanya cessie, tidak perlu dilakukan penghapusan pencatatan hak tanggungan terlebih dahulu untuk kemudian didaftarkan hak tanggungan baru lagi. Karena dengan cessie, lunasnya utang debitur kepada kreditur lama, akan tetapi belum lunas pada kreditur baru. Sehingga dapat dikatakan utang debitur belum berakhir, sedangkan pencatatan roya baru dapat dilakukan bilamana utang debitur telah lunas dan utang piutang dapat dinyatakan berakhir. Sebab itu, kreditur baru akan memberitahukan pada Badan Pertanahan Negara dengan mendaftarkan peralihan hak tanggungan dari kreditur lama untuk atas nama dirinya. ${ }^{50}$

Cara untuk memperoleh hak milik atas suatu kebendaan tak dapat diperoleh dengan cara lain, melainkan dengan pemilikan, karena perlekatan, karena kedaluarsa, karena pewarisan, baik menurut undang-undang maupun menurut surat wasiat, dan karena penunjukan tau penyerahan berdasarkan atas suatu peristiwa perdata untuk memindahkan hak milik, dilakukan oleh seseorang yang berhak berbuat bebas terhadap kebendaan itu. ${ }^{51}$

Skema cessie pihak yang menyerahkan atau mengalihkan piutangnya itu disebut sebagai Cedent, dan pihak yang menerima penyerahan atau pengalihan piutang disebut Cessionaris, kemudian debitur dari tagihan yang dialihkan disebut Cessus. Penyerahan utang piutang kebendaan tak bertubuh dan atas nama dilakukan dengan dibuatkan atau dilakukan pendaftaran atau pembuatan akta otentik atau di bawah tangan dengan hakhak atas kebendaan dilimpahkan kepada orang lain. ${ }^{52}$

Dengan adanya skema cessie, maka akibat hukumnya yaitu:

a) Piutang beralih dari cedent ke cessionaris;

b) Setelah cessie terjadi atau berlaku, kedudukan dari cessionaris akan menggantikan kedudukan cedent, yang berarti bahwasanya segala hak yang telah dimiliki oleh cedent terhadap cessus dapat digunakan oleh cessionaris sepenuhnya. ${ }^{53}$

Pengalihan piutang dalam cessie memberikan hak untuk penerima cessie dalam hal ini adalah cessionaris sebagai kreditur yang baru bagi debitur atau cessus sehingga hubungan berikutnya yaitu antara kreditur yang baru dengan segala akibat hukum dari

\footnotetext{
49 Ibid.

${ }^{50}$ Ibid.

${ }^{51}$ Lihat Pasal 584 KUHPerdata.

${ }^{52}$ Herlien Budiono, Ajaran Umum Hukum Perjanjian dan Penerapan di Bidang Kenotariatan, (Bandung: Citra Aditya, 2010), 185.

${ }^{53}$ Rahman Setiawan dan J. Satrio, Penjelasan Hukum tentang Cessie, (Jakarta: PT. Gramedia,
} 2010) 56. 
peralihan piutang itu memberikan hak untuk kreditur yang baru untuk mengajukan gugatan kepada debitur. ${ }^{54}$

\section{Upaya Hukum Cessionaris atas Hak Tagih Jaminan Hak Tanggungan Berdasarkan Pengalihan diutang (Cessie)}

Cessie merupakan salah satu cara untuk memperoleh hak milik. Penyerahan dalam proses cessie adalah penyerahan tagihan atas nama dari cedent ke cessionaris. Telah dijelaskan bahwa yang dimaksud dengan tagihan atas nama adalah tagihan atau piutang yang jelas atas nama krediturnya (dalam hal ini apabila cessie belum dilakukan maka tagihan atau piutang masih atas nama kreditur lama). Tagihan atas nama jelas kepada siapa utang tersebut harus dibayar. ${ }^{55}$ Dalam proses cessie tindakan penyerahan tidak berdiri sendiri, tindakan tersebut selalu merupakan konsekuensi lebih lanjut dari suatu peristiwa hukum, yang mewajibkan orang untuk menyerahkan sesuatu. Hubungan hukum yang mewajibkan adanya penyerahan disini disebut sebagai hubungan hukum obligatoir, yang bisa timbul dari perjanjian maupun dari undangundang. Hubungan hukum obligatoir dalam proses cessie termasuk yang timbul dari perjanjian karena muncul karena diperjanjikan antara para pihak. Kita ketahui suatu perjanjian obligatoir adalah perjanjian yang menimbulkan hak dan kewajiban antara para pihak. Peristiwa yang menjadi dasar penyerahan yang disebut peristiwa perdata atau rechtstitel adalah peristiwa yang menimbulkan perikatanperikatan diantara dua pihak, dimana yang satu berkedudukan sebagai kreditur dan pihak lain berkedudukan sebagai debitur. Jadi peristiwa perdata (rechtstitel) tersebut adalah hubungan obligatoir yang menjadi dasar cessie. ${ }^{56}$

Mengenai cessie berarti intinya perjanjian atau perikatan, karena cessie merupakan hubungan hukum yang terjadi karena persetujuan atau kesepakatan para pihak, yakni hubungan yang menimbulkan akibat hukum yaitu hak dan kewajiban. ${ }^{57}$ Hal ini berarti bahwa cessie yang dibuat secara sah mengikat para pihak sebagaimana undangundang dan perikatan ini hanya berlaku bagi para pihak yang berkepentingan dalam perjanjian cessie saja. Cessie dibuat yang isinya adalah untuk mengalihkan hak atas tagihan, maka setelah cessie dibuat dan disepakati oleh para pihak demi hukum hak milik dari kebendaan bergerak berupa piutang atas nama dan kebendaan tidak bertubuh lainnya, secara otomatis beralih dari kreditur semula kepada kreditur baru. ${ }^{58}$

Upaya hukum yang dilakukan dalam pengalihan piutang dengan skema cessie ini dapat melalui gugatan contentiosa maupun gugatan voluntair, dan juga pengajuannya juga dapat diajukan di pengadilan agama maupun pengadilan negeri. Jika perkara cessie tersebut berada pada pihak perbankan syariah maka perkara itu dapat di daftarkan pada pengadilan agama sesuai dengan kompetensinya masingmasing sesuai dengan ketentuan perundang-undangan dalam kaitannya dengan kompetensi mengadili maupun kompetensi lainnya. Kemudian, jika perkara cessie tersebut berada pada pihak perbankan umum atau dengan kata lain bank konvensional, maka gugatan dapat diajukan ke pengadilan negeri sesuai dengan kompetensinya masing-masing. Dalam bentuk gugatan yang diajukan juga bisa menggunakan gugatan

${ }^{54}$ Ibid, 58.

${ }^{55}$ Lihat Pasal 613 KUH Perdata.

${ }^{56}$ Rachmad Setiawan, J. Satrio, Penjelasan Hukum tentang Cessie, (Jakarta: National Legal Reform Program, 2010), 4.

${ }^{57}$ Lihat Pasal 1338 KUH Perdata: semua perjanjian yang dibuat secara sah berlaku sebagai undang-undang bagi mereka yang membuatnya.

${ }^{58}$ Wawan Iriawan, Cessie, Piutang Kredit, Hak Dan Perlindungan Bagi Kreditur Baru, (Jakarta: Djambatan, 2005), 69. 
voluntair maupun gugatan contentiosa. Jika ada sengketa pada perkara cessie tersebut seperti debitur lama untuk mengosongkan kediaman yang akan dibeli oleh debitu baru maka dapat dimintakan kepada hakim dalam petitum gugatan untuk mengosongkan rumah tersebut dalam keadaan benar-benar kosong di pengadilan. Namun jika perkara pengalihan piutang dengan skema cessie tersebut tidak mengandung sengketa maka dapat diajukan gugatan voluntair atau mengajukan sebuah permohonan ke pengadilan sesuai dengan kompetensinya baik kompetensi absolut maupun kompetensi relatifnya harus disesuaikan agar tidak menyalahi perundang-undangan atau peraturan yang berlaku. ${ }^{59}$

Gugatan yang dimaksud adalah mengajukan gugatan wanprestasi atau ingkar janji atas perjanjian kredit pada Pengadilan Negeri. Menurut analisis penulis, langkah ini memang tepat dilakukan dengan dasar analisis sebagai berikut:

1. Kewajibannya Perikatan sebagai sumber prestasi dibagi menjadi 2 (dua) yaitu Perikatan yang bersumber pada undang-undang dan Perikatan yang bersumber pada perjanjian. ${ }^{60}$

2. Dengan terpenuhinya syarat sahnya perjanjian, yaitu: a) Adanya kesepakatan para pihak; b) Adanya kecakapan untuk membuat perjanjian; c) Adanya hal tertentu; d) Sebab yang halal ${ }^{61}$. Dan Perjanjian yang dibuat oleh kedua belah pihak merupakan undang-undang bagi mereka. ${ }^{62}$

3. Perjanjian Pengalihan Piutang (Cessie) tersebut telah dilaksanakan sesuai dengan aturan dan prosedur yang benar, sehingga cessie tersebut sah dan mempunyai akibat kepada debitur; ${ }^{63}$

4. Kreditur baru harus melakukan pemberitahuan mengenai Cessie dan melakukan penagihan kepada Debitur;

5. Setiap Debitur hanya diwajibkan mengganti biaya, kerugian dan bunga, yang diharapkan atau sedianya dapat diduga pada waktu perikatan diadakan, kecuali jika tidak dipenuhinya perikatan itu disebabkan oleh tipu daya yang dilakukannya; ${ }^{64}$

6. Dengan tidak dipenuhinya perikatan itu disebabkan oleh tipu daya debitur, maka penggantian biaya, kerugian dan bunga, yang menyebabkan kreditur menderita kerugian dan kehilangan keuntungan hanya mencakup hal-hal yang menjadi akibat langsung dari tidak dilaksanakannya perikatan itu, ${ }^{65}$

7. Apabilah pihak yang terhadapnya perikatan tidak dipenuhi, dapat memilih memaksa pihak yang lain untuk memenuhi persetujuan, jika hal itu masih dapat dilakukan, atau menuntut pembatalan persetujuan, dengan penggantian biaya, kerugian dan bunga; 66

Ketentuan hukum yang harus diterapkan adalah jual beli tanah yang harus sesuai dengan yang diatur di dalam Undang-Undang Nomor 5 Tahun 1960 tentang UndangUndang Pokok Agaria dan Peraturan Pemerintah Nomor 10 Tahun 1961 yang di ganti dengan Undang-Undang Nomor 24 Tahun 1997 Tentang Pendaftaran tanah. Bahwa jual beli tanah seharusnya dilakukan dihadapan PPAT dengan dibuatkan suata akta

${ }^{59}$ Ade Darmawan Basri, Pengalihan Piutang Dengan Skema Cessie Dalam Hukum Perbankan Syariah Maupun Konvensional, Jurnal El-Iqtishady, Volume 2 Nomor 1 Juni 2020, Fakultas Syariah dan Hukum Universitas Islam Negeri Alauddin Makassar 13-14.

${ }^{60}$ Lihat Pasal 1234 Kitab Undang-undang Hukum Perdata.

${ }^{61}$ Lihat Pasal 1230 Kitab Undang-undang Hukum Perdata.

${ }^{62}$ Lihat Pasal 1338 Kitab Undang-undang Hukum Perdata.

${ }^{63}$ Lihat Pasal 613 Kitab Undang-undang Hukum Perdata.

${ }^{64}$ Lihat Pasal 1247 Kitab Undang-undang Hukum Perdata.

${ }^{65}$ Lihat Pasal 1248 Kitab Undang-undang Hukum Perdata.

${ }^{66}$ Lihat Pasal 1267 Kitab Undang-undang Hukum Perdata. 
jual beli tanah. ${ }^{67}$ Jika didalam proses jual beli dapat dengan mudah melakukan balik nama terhadap sertipikat dari tanah yang menjadi obyek peralihan tersebut, maka berbeda dengan cessie yang pastinya mengalami kesulitan untuk melakukan balik nama di Badan Pertanahan Nasional (BPN). Hal tersebut dapat terjadi sebab cessie hanya bentuk dari peralihan piutang saja tanpa mengalihkan hak kepemilikan. ${ }^{68}$

Untuk dapat melakukan peralihan nama sertipikat, pembeli cessie membutuhkan Badan Pertanahan Nasional (BPN) sebagai kepanjangan tangan pemerintah dalam hal kepengurusan tanah. Namun pihak Badan Pertanahan Nasional (BPN) tidak menerima akta cessie semata sebagai dasar untuk peralihan nama di sertifikat, sehingga pembeli cessie harus mengajukan permohonan ke Pengadilan Negeri terlebih dahulu, agar dari ketetapan Pengadilan Negeri tersebut dapat menjadi dasar peralihan nama (didalam penetapannya, Pengadilan Negeri memerintahkan Badan Pertanahan Nasional (BPN) untuk dapat mengalihkan nama yang tertulis di sertifikat menjadi nama pembeli cessie. ${ }^{69}$

\section{KESIMPULAN}

Perkawinan anak di bawah umur merupaka suatu fenomena sosial yang kerap terjadi, khususnya di Indonesia. Fenomena perkawinan anak di bawah umur, apabila di ibaratkan akan menjadi seperti fenomena gunung es, sedikit dipermukaan atau yang terekspos dan sangat marak di dasar atau di tengah masyarakat luas. Pemerintah harus sangat berkomitmen serius dalam menegakakan hukum yang berlaku mengenai perkawinan di bawah umur, sehingga pihak-pihak yang ingin melakukannya dapat berfikir dua kali apabila ingin melakukan hal tersebut. Selain itu Pemerintah harus semakin mensosialisasikan Undang-undang terkait beserta sanksi-sanksi apabila ada masyarakat yang melanggarnya.

\section{SARAN}

Upaya hukum upaya hukum cessionaris terhadap hak tagih atas jaminan hak tanggungan berdasarkan pengalihan hutang (cessie) adalah mengajukan gugatan wanprestasi atau ingkar janji atas perjanjian kredit pada Pengadilan Negeri, dengan dasar pertimbangan, yaitu a) Kewajibannya Perikatan sebagai sumber prestasi dibagi menjadi 2 (dua) yaitu Perikatan yang bersumber pada undang-undang dan Perikatan yang bersumber pada perjanjian; b) Dengan terpenuhinya syarat sahnya perjanjian, yaitu: 1) Adanya kesepakatan para pihak; 2) Adanya kecakapan untuk membuat perjanjian; 3) Adanya hal tertentu; 4) Sebab yang halal. Dan Perjanjian yang dibuat oleh kedua belah pihak merupakan undang-undang bagi mereka; c) Perjanjian Pengalihan Piutang (Cessie) tersebut telah dilaksanakan sesuai dengan aturan dan prosedur yang benar, sehingga cessie tersebut sah dan mempunyai akibat kepada debitur; d) Kreditur baru harus melakukan pemberitahuan mengenai Cessie dan melakukan penagihan kepada Debitur; e) Setiap Debitur hanya diwajibkan mengganti biaya, kerugian dan bunga, yang diharapkan atau sedianya dapat diduga pada waktu

${ }^{67}$ Abdul Wahid, Elya Kusuma Dewi, Sarip, Upaya Hukum Penyelesaian Sengketa Jual Beli Tanah Secara Di Bawah Tangan, Jurnal Mahkamah: Jurnal Kajian Hukum Islam, Vol. 4, No. 2, Desember 2019, Department of Family Law (Al-Ahwal Al-Syakhsiyyah) Faculty of Shariah and Islamic Economics IAIN Syekh Nurjati Cirebon, 22-35.

${ }^{68}$ Lihat Pasal 1 dan 2 Undang-Undang Badan Pertanahan Nasional BPN, Peraturan Presiden Republik Indonesia Nomor 10 Tahun 2006 Tentang Badan Pertanahan Nasional.

${ }^{69}$ Lihat Pasal 621 KUHPerdata. 
perikatan diadakan, kecuali jika tidak dipenuhinya perikatan itu disebabkan oleh tipu daya yang dilakukannya; f) Dengan tidak dipenuhinya perikatan itu disebabkan oleh tipu daya debitur, maka penggantian biaya, kerugian dan bunga, yang menyebabkan kreditur menderita kerugian dan kehilangan keuntungan hanya mencakup hal-hal yang menjadi akibat langsung dari tidak dilaksanakannya perikatan itu; g) Apabilah pihak yang terhadapnya perikatan tidak dipenuhi, dapat memilih memaksa pihak yang lain untuk memenuhi persetujuan, jika hal itu masih dapat dilakukan, atau menuntut pembatalan persetujuan, dengan penggantian biaya, kerugian dan bunga.

Pembeli cessie harus mengajukan permohonan ke Pengadilan Negeri terlebih dahulu, agar dari ketetapan Pengadilan Negeri tersebut dapat menjadi dasar peralihan nama (didalam penetapannya, Pengadilan Negeri memerintahkan Badan Pertanahan Nasional (BPN) untuk dapat mengalihkan nama yang tertulis di sertifikat menjadi nama pembeli cessie.

\section{UCAPAN TERIMA KASIH}

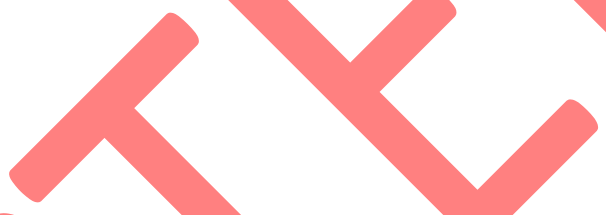

Alhamdulillah puji syukur kepada Allah swt, karena kehendak dan ridha-Nya peneliti dapat menyelesaikan penelitian ini. Peneliti sadari penelitian ini tidak akan selesai tanpa doa, dukungan dan dorongan dari berbagai pihak. Adapun dalam kesempatan ini peneliti ingin mengucapkan banyak terima kasih kepada Dekan Fakultas Hukum, Ketua program Studi Ilmu Hukum dan Rekan Dosen dari Universitas Bhayangkara Jakarta Raya dan Universitas Muhammadiyah Cirebon serta semua pihak yang tidak dapat disebutkan satu persatu, terima kasih atas segalanya.

Buku:

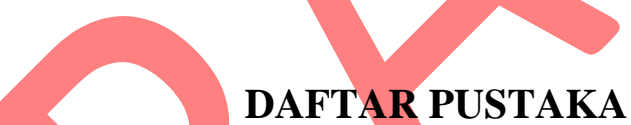

Fuady Munir, Hukum Tentang Pembiayaan, cet IV, (Bandung Citra Aditya Bakti, 2006).

Hasan Djuhaendah, Lembaga Jaminan Kebendaan Bagi Tanah dan Benda Lain Yang Melekat Pada Tanah Dalam Konsepsi Penerapan Asas Pemisahan Horisontal, (Bandung: PT. Citra Aditya Bakti, 1996).

Herlien Budiono, Ajaran Umum Hukum Perjanjian dan Penerapan di Bidang Kenotariatan, (Bandung: Citra Aditya, 2010).

Iriawan Wawan, Cessie, Piutang Kredit, Hak Dan Perlindungan Bagi Kreditur Baru, (Jakarta: Djambatan, 2005).

M. Endriyo Susila et al, Buku Pedoman Penulisan Hukum, (Yogyakarta: Fakultas Hukum Universitas Muhammadiyah Yogyakarta, 2007).

Mariam, Darus Badrulzaman, Buku II Kompilasi Hukum Jaminan, (Bandung: Mandar Maju, 2004).

Marzuki Peter Mahmud, Penelitian Hukum, (Jakarta: Kencana, 2009).

Mertokusumo, Sudikno, Hukum Acara Perdata Indonesia, (Yogyakarta: Penerbit Liberty, 2009). 
Muljadi Kartini, Gunawan Widjaja, Seri Hukum Harta Kekayaan: Hak Tanggungan, (Jakarta, Prenada Media, 2004).

Purwahid Patrik dan Kashadi, Hukum Jaminan Edisi Revisi Dengan Undang-Undang Nomor 4 Tahun 1996 Tentang Hak Tanggungan, (Semarang: Fakultas Hukum Universitas Diponegoro, 2006).

Rachmadi Usman, Hukum Jaminan Keperdataan, Jakarta: Sinar Grafika, 2008.

Salim H.S, Perkembangan Hukum Jaminan Di Indonesia, (Jakarta: PT. Raja Grafindo Persada, 2004).

Satrio J., Hukum Jaminan, Hak Jaminan Kebendaan Hak Tanggungan, (Bandung: PT. Citra Aditya, 1997).

Satrio J., Parate Eksekusi Sebagai Sarana Mengatasi Kredit Macet, (Bandung: Citra Aditya Bhakti, Bandung, 1993).

Setiawan, Rachmadi dan J. Satrio, Penjelasan Hukum tentang Cessie, (Jakarta: Gramedia, 2010).

Soekanto Soerjono dan Sri Mamudji, Penelitian Hukum Normatif, Suatu Tinjauan Singkat, (Jakarta: Raja Grafindo Persada, 2011).

Soeharnoko dan Endah Hartati, Doktrin Subrogasi, Novasi dan Cessie, (Jakarta: Kencana, 2008).

Sutedi Adrian, Hukum Hak Tanggungan, Jakarta: Sinar Grafika, 2010.

\section{Jurnal:}

Abdul Wahid, Elya Kusuma Dewi, Sarip, Kekuatan Alat Bukti Akta Otentik Terhadap Akta Pejabat Pembuat Akta Tanah (PPAT) Berdasarkan Peraturan Pemerintah Nomor 24 Tahun 2016 Juncto Pasal 1868 KUHPerdata, Jurnal Mahkamah: Jurnal Kajian Hukum Islam, Vol. 4, No. 2, Desember 2019, Department of Family Law (Al-Ahwal Al-Syakhsiyyah) Faculty of Shariah and Islamic Economics IAIN Syekh Nurjati Cirebon.

Abdul Wahid, Elya Kusuma Dewi, Sarip, Upaya Hukum Penyelesaian Sengketa Jual Beli Tanah Secara Di Bawah Tangan, Jurnal Mahkamah: Jurnal Kajian Hukum Islam, Vol. 4, No. 2, Desember 2019, Department of Family Law (Al-Ahwal Al-Syakhsiyyah) Faculty of Shariah and Islamic Economics IAIN Syekh Nurjati Cirebon.

Akhmad Budi Cahyono, Cessie Sebagai Bentuk Pengalihan Piutang Atas Nama, Lex Jurnalica/ Vol. 2 /No.1/ Desember 2004.

Basri Ade Darmawan, Pengalihan Piutang Dengan Skema Cessie Dalam Hukum Perbankan Syariah Maupun Konvensional, Jurnal El-Iqtishady, Volume 2 Nomor 1 Juni 2020, Fakultas Syariah dan Hukum Universitas Islam Negeri Alauddin Makassar.

David Simatupang, Sengketa Hak Atas Tanah Melalui Akta Cessie (Studi Kasus Putusan Mahkamah Agung NO 308/PK/PDT2016 Jo Kasasi NO 1625 K/PDT/2014), Jurnal Hukum: Hukum Untuk Mengatur Dan Melindungi Masyarakat, Fakultas Hukum Universitas Kristen Indonesia, Volume 6, No. 1 bulan April 2020. 
Feronika Y. Yangin, Analisis Hukum Pengalihan Piutang (Cessie) Kepada Pihak Ketiga Menurut Pasal 613 KUH Perdata, Jurnal Lex Privatum, Vol. IV/No. 5/Juni/2016.

Gita Permata Aulia, Endang Sri Kawuryan, Perlindungan Hukum Terhadap Pembeli Cessie Dalam Melakukan Balik Nama Sertipikat Hak Atas Tanah Dan Bangunan, Jurnal Transparansi Hukum: Volume 1, Nomor 1, Januari 2018.

Padmasari Widya, Perlindungan Hukum Bagi Para Pihak Dalam Pengalihan Piutang (Cessie) Melalui Akta Notaris, Jurnal Hukum dan Kenotariatan, Volume 2 Nomor 2 Agustus 2018, Pascasarjana UNISMA.

\section{Peraturan Perundang-undangan:}

Kitab Undang-Undang Hukum Perdata.

Undang - Undang Nomor 4 tahun 1996 tentang Hak Tanggungan.

Undang-Undang Badan Pertanahan Nasional BPN, Peraturan Presiden Republik Indonesia Nomor 10 Tahun 2006 Tentang Badan Pertanahan Nasional.

Undang-Undang Republik Indonesia Nomor 2 Tahun 2014 Tentang Perubahan Atas Undang-Undang Nomor 30 Tahun 2004 Tentang Jabatan Notaris. 